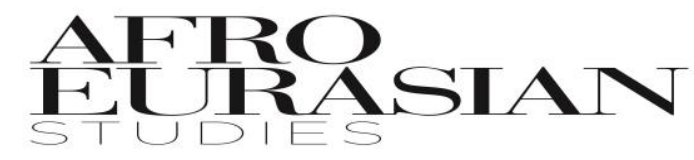

[Afes], 2018, 7 (1): 99-137

\title{
The Impact of The OECD On the Turkish Foreign
}

Trade

\begin{tabular}{|c||} 
Recep ÖZDİREK \\
\hline $\begin{array}{c}\text { Asst. Prof. Dr., Department of Islamic Law, Faculty of } \\
\text { Theology Kastamonu University, } \\
\text { rozdirek@kastamonu.edu.tr } \\
\text { Orcid Id:0000-0003-4335-9745 }\end{array}$ \\
\hline
\end{tabular}

\section{Article Information}

Article Types : Research Article

Received : :12.11.2018

Accepted : :29.12.2018

Published : 31.12 .2018

Pub Date Season: Spring

Cite as: ÖZDİREK, R. (2018). Legal-Economic Analysis of the Inability to Give Alms to the Family of Muhammad Because of Being the Relatives of the President. Afro Eurasian Studies, 7 (1), 99-137. Retrieved from http://dergipark.gov.tr/afes/issue/39788/472125

Plagiarism: This article has been reviewed by at least two referees and scanned via a plagiarism software.

Copyright $(\mathcal{C}$ Published by MUSIAD- Sutluce Mah. Imrahor Cad. No:28 34445 Beyoglu Istanbul- Turkey Phone: +90 - 212 - 3950000 Fax: +90 212 - 3950001 E-mail: aestudies@musiad.org.tr 


\title{
Legal-Economic Analysis of the
}

\section{Inability to Give Alms to the}

\section{Family of Muhammad Because of}

\section{Being the Relatives of the}

\section{President}

\begin{abstract}
Alms/zakat is the financial worship of where it can be given fixed by the verses [of Qur'an]. The need of the poor, needy, stranded, mujahid, debtor who cannot pay their debt, and the alms officer are fulfilled from this item. Among those who cannot be given alms include the relatives of the Prophet. They cannot receive alms even if they cannot meet their basic needs. For them, allowances are allocated from the [war] booty and prize items of state income. In this article, which relatives of the Prophet are prohibited to take alms, the reasons behind it, and the justifications in the figh (Islamic law) books for that are going to be identified. The religious and legal grounds explained by the Fukaha
\end{abstract}


(Islamic jurists) that Prophet accepted alms goods as "dirty" to those outside the allowed list will be determined and an attempt to make a new explanation will be made.

Keywords: Muhammad Family, Alms/Zakat, Prophet, Economic, Analysis.

\section{Introduction}

Alms is the worship, of which the income sources and places can be given designated by Allah. Alms has the characteristics that require it to be considered as tax and it has features that distinguish it from taxes. It is one of the most important issues of the Islamic economy. One of the characteristics of alms is preventing the wealth and fortune to "cycle within the rich" that is forming an economic monopoly.

The Prophet Muhammad stated that alms-receiving, a kind of social security for the needy and poor in Islamic society, is haram (forbidden) for his relatives. He had been very careful not to eat the alms properties goods in his life, even prevented his grandson Hasan eating a date found in the ground and had taken with a childhood reflex. He tried to solve the situation of the poor and needy of his relatives who could not meet the basic needs from sources other than alms. 
The issue of the president of the state providing economic privileges for their relatives is an issue that has been continuously discussed in different aspects throughout history. It has been studied in various fields of science such as history, law, politics, and economics. Here, the matter of "Family of Muhammad: the relatives of the Prophet" prohibited to receive alms that has special importance in terms of Islamic history and law will be discussed in terms legal aspect and will be tried to analyzed with regards to economics.

Alms is one of the basic worship of Islam. Worship is one of the basic pillars of our spiritual world. Therefore, the religion is likened to a building in the hadith "Islam is founded on five pillars" (Bukhari, Iman: 1). Basic worship was accepted as columns and beams that keep this building standing. One of these basic worship is alms. Alms contributes many things both individually and socially. Almighty Lord by addressing to the Prophet, "Take, [O, Muhammad], from their wealth a charity by which you purify them and cause them increase" (at-Tawbah, 9: 103), clearly stated that giving alms will clean and purify a Muslim. While the places that can be given alms were revealed in the verses, the people who were supposed to give it and the proportions they need to give were taught by the Sunnah of the Prophet. One of the groups who cannot be given alms were dealt in the hadiths and based on these 
in the books of fiqh under the title "Muhammad's family" and Hashemites.

In Islam, a special importance given to the family, close relatives, and descendants of the Prophet, and to show the necessary respect, love, and courtesy to them is considered to be a religious obligation (ash-Shuraa, 42: 23) (Buzpinar, $2006,324)$ In spite of their values and importance, the prophet family was banned from taking alms by the Prophet himself even if they possessed the property of being poor, which is the necessary requirement to take alms. In this study, the issues such as the reasons and wisdom of the prohibition, who is covered by the ban, the conditions, whether the prohibition is temporary or permanent, and whether it changes with the change of the time, place, and conditions, will be discussed.

The subject is given under the title "those of whom receiving alms are not halal" in fiqh books. Along with the scholars dealing with the issue broadly, there have also been a number of investigators who have examined the case separately and literature has been formed and the different aspects of the issue have been addressed. These works will be identified and briefly introduced starting from the last one below.

1- Yüksel Macit, "On Ahl al-Bayt not Taking Charity or Alms", Marife magazine, Year: 4, Number: 3, Winter 2004. 
Marife magazine has prepared this number as a Special Ahl al-Bayt issue. Various issues related to Ahl al-Bayt are discussed in this issue and the matter of them not being allowed to receive alms is also explored in this article.

2- Seyyid Feyzullah (Erzen) (1932-2002): Zekatü'l-mâl tahillü li'l-âl: This booklet, which was completed in 1998, has not been published yet. Seyyid Feyzullah is a valuable mudarris and Sufi, who has been a mudarris and imam for many years, stayed in Iraq and Syria and has contact with the scholars around there. He saw the sayyids and the sharifs in the poor and difficult states suffering for not receiving alms and tried to prove that they could receive alms through various evidence. In this booklet, he has used lots of classic and modern works as the sources such as the relevant section of the Yusuf el-Karadavi, "Frkhu'zZekat" (Law of Alms).

3- Seyyid Ali Findıkî (Erzen) (1893-1968): “el-İnsaf fi cevazi'z-zekat ile'l-eşrâf" in Mecmuatu'r-resâil. Said Erzen, Istanbul, 2010, Print: Ravza Publishing, sh. 131-160. Various masterpieces of Seyyid Ali Findıkî, one of the prominent mudarris, Sufis, and poets of Şırnak region in the Republican period, were brought together and published by his student and nephew Said Erzen. In this booklet, it is dealt in accordance with the Shafi'i school sources with the proofs that the sayyids and the sharifs 
who have economic difficulties due to poverty can get alms and some proofs are put forward in terms of methodology as well

These two booklets are efforts to find solutions for the sayyids and the sharifs in Turkey in need of alms due to their poverty. The uncle and the nephew, Seyyid Ali Fındıkî (Erzen) and Seyyid Feyzullah Erzen, two valuable mudarris who themselves were Ahl al-Bayt, are the famous figures of eastern madrasahs. They concluded that it would be possible to give alms to the Ahl al-Bayt in their booklets. The fatwa in these two booklets provides a solution for the members of Ahl al-Bayt who are poor and in need as well as are the sayyids and the sharifs mudarrises who does not have any income for their living but the alms provided by the villagers.

The eastern madrasas are teacher (hodja/master)-centered madrasas. If a madrasa is desired to be opened in a place, a scholar is invited there as imam and a mudarris, so that they perform their imam duties and give madrasa education to the students. All kinds of needs of this teacher and students were covered by the public. Therefore, the number of students studying at the madrasa was determined by the financial means of the village or settlement. The financial support provided by the villagers to the teacher and the students was largely 
alms. As such, the issue of sayyid mudarrises, who have no income other than alms, receiving alms was discussed from time to time. Those who have continued this duty as civil servants, especially those who are sayyid are careful about not taking alms, yet, for those who have this opportunity, alms is the only source of income.

4- Yusuf el-Karadavi: "Frkhu'z-Zekat", Dâru müesseseti'rrisâle, Beirut, 1973, pp. 728-739. Yusuf el-Karadâvî spared an independent section on those who were forbidden to receive alms, and he concluded that Ahl al-Bayt can be given alms with considering the "conclusions/clauses change according to time" principle and a number of other evidences on the question whether the Prophet's family can be given alms or not.

5- Tahâvî (v.321): Şerhu maâni'l-âsâr, Âlemü'l-kütub, 1994 v.II, pp. 3-13. In this work, Tahâvî, in the beginning of Zakat book, opened an independent title called "Section of Charity to the Banu Hashim", and explained here who is accepted as Banu Hashim and whether they can be given alms or not with the hadith and works on the subject by specifying their criticism as together. This work of Tahâvî, which can be considered as a separate booklet, is of particular importance in terms of its width, its ability to address different aspects of the issue and to examine the different opinions on it one by one in terms of its content. 
People who can be given zakat are listed in the Qur'an as follows: "Zakat expenditures are only for the poor and for the needy and for those employed to collect [zakat] and for bringing hearts together [for Islam] and for freeing captives [or slaves] and for those in debt and for the cause of Allah and for the [stranded] traveler - an obligation [imposed] by Allah. And Allah is Knowing and Wise" (atTawbah, 9: 60).

The Prophet, related to the people who will be given alms in this verse, defined some limitations. If a person is poor and needy, or an alms officer, but also a member of Hashemites, alms will not be halal to them. There may be other limitations to those who will be given these alms. Just like the fact that one giving alms to their poor wife, son, daughter, and parents is not halal. It is not permissible for these people to receive alms, and the person who gave the alms goods to them is not considered to have performed this worship. Due to the importance of the issue, Islamic jurists attached special importance to deciding the people who cannot be given alms as well as those who can be given. The issue of whether Hashemites can or cannot be given alms is counted under a separate point as "being Hashemites", as well as discussed while the points of being poor, alms officers were being dealt. 


\section{Prophet's Relatives (Hashemites/Muhammed's}

\section{Family/Ahl al-Bayt)}

While those who cannot be given alms in fiqh books are counted as items in relatives of the Prophet counted as a separate group. The scholars in different sects preferred different words for the terminology of this group such as "Hashemite", "Banu Hashim", "ademi bunuvvetin li Hashim" "ahl al-bayt", "el-âl", "alu'l-beyt", ahl al-bayt-u Rasulullah, al-bayt-u Muhammad, ahl al-Muhammad, ahl alnabi". Despite different nomenclature, there is a great deal of alliance on who is implied with those terms.

Various scientific studies have been done to determine the meanings of these concepts used in religious literature. Because the issue has importance for the disciplines outside the fiqh such as akaid (doctrine), tafsir (interpretation), hadith, sectarian history, affiliation, Islamic history. These concepts are discussed in sections such as prize, booty, salaah, and inheritance, apart from the zakat. We have compiled the information on the subject mainly by scanning sections related to zakat and prize (booty). Accordingly, those who cannot be given alms is mentioned in the hadiths as follows:

1- Hashemites: The Islamic jurists agree the fact that they cannot be given alms. Although the term "Hashemite" is used for those who are not allowed to receive alms in the 
hadiths, various criticisms have been made about the [chains] of narrations (riwayah) (Zeylâî 1997: II/487). Scholars determined that it is the "Hashemites" being referred to as those cannot be given alms because of the use of "al-" prefix. Al- refers to relatives of a person through their grandfather. These are Abdullah, Abd al-Muttalib (Shayba), and Hashim. Accordingly, close relatives of the Prophet are the lineage of Prophet Muhammad who is included directly or through their father up to the Hashim. Among the four sons of Hashim, only Abd al-Muttalib (Shayba)'s lineage continued (Taberî 1968: III/1082). Hashim had four sons and five daughters. His offspring only continued through his son Shayba (Abd al-Muttalib), among the sons. These descendants are called as Hashemites (Banu Hashim). Of the ten sons of Abd al-Muttalib, his offspring did not continue through Hamza, Zubeyr, Hajel, Dirar, and Mukavvim. Abdullah's lineage continued through the Prophet's daughter Fatima. The kinship of Abû Lahab (honor and other rights to be obtained by his kinship) was canceled with the hadith. Abd al-Muttalib's offspring continued through his sons Abbas, Al-Harith, and Abû Tâlib children continued. Abu Tâlib's lineage continued through his sons Aqeel, Ja'fer, and Ali. Those who are close to Ali were called as the "Alevi", and among his children from Fatima, Hasan's descendants are called sharifs and Husayn's 
descendants are called sayyid. Ali has children apart from these two, Muhammad ibn al-Hanafiyyah, of which his lineage continued (Özel, 1989: II/305-306; Öz 1994: X/409502).

There is an agreement between the Hanafi, Maliki, Shafi'i, and Hanbali schools about the fact that Hashemites cannot be given alms (Kâsânî, 1986: II/49).

2- Prophet's Wives: There are narrations that the women of the Prophet will be evaluated within the "al-" concept. On the subject of the concept of "ahl", there is some evidence from the Qur'an and the Sunnah that the wife of the person is included in this concept (Öz 1994: X / 498-501). İbn Kudâme (1998: IV / 112) shown Aisha's following report as evidence to that the women of the Prophet should be counted as "al-":

Khalid ibn Sa'd ibn al-'As send some of his alms goods to Aisha. Aishe rejected saying "We are al-Muhammad, alms are not halal for us." (Müslim, Zakat: 168).

While Ibn Battal in his Bukhari commentary, conveying his opinion on this subject stating Prophet's wives are out of this concept, the opinion of Ibn Qudama in al-Muqni indicates that there are those who think differently about it. Ibn Hajar pointed out that this hadith's referral to the Aisha is hasan (good but not sahih [authentic]), Ibn Munîr participating in 
the opinion of Ibn Battal also pointed out that giving alms to them was not haram (Tehanevi, 2001: IX/94).

3- Abû Lahab's lineage: The Prophet's uncle Abû Lahab, although he is a relative of Prophet Muhammad in terms of kinship, due to its hostile attitude towards Muslims, especially Prophet, juristically he was not accepted as "alMuhammad" because of his inappropriate attitude in terms of kinship. He has forfeited of dignity, honor, and some other rights they had. The vast majority of Islamic jurists agreed that Abû Lahab and his descendants could not be considered in the al-Muhammad (İbn Hümam, 2003: $\mathrm{IV} / 2008$ ). There is a narration that it is not halal to give alms to descendants of Abû Lahab either, from one of the Hanafi scholars, İsbîcâbî. (Aynî 1990: III/471) Hanbali scholar Ibn Qasim al-Asim has stated that there are two views on this issue and there is a dispute over Abû Lahab. He says that with being Prophet Muhammad's uncle his kinship is very close to the Prophet so that the descendants of him cannot take alms. As a second view, states that he had fought against the Prophet Muhammad, so the Surah al-Massad was revealed [condemning him], yet, the relatives of the Prophet cannot be given alms due to honoring and respecting, and so this is not a matter of Abû Lahab. It is reported that Abu Leheb had two sons, Utaybah and Muattab, that they were converted to Islam in the conquest 
of Mecca and participated in the battles of Hunayn and Taif, but they did not migrate to Medina and remained in Mecca (İbn Kâsım 1397: II / 99). It is also said that Abû Lahab's daughter Durrah converted to Islam and settled in Medina and that some in Medina insulted her because of his father, thereupon, the Prophet warned those with declaring her as his relative (İbn Sa'd, III/45; Yardım, 1994: X/31).

4- Muttalibis: There are two opinions about whether or not the descendants of Muttalib can be counted from alMuhammad, and thus, can take alms or not.

a) Those who accept Muttalibis as al-Muhammad: The scholars of Shafi'i school and Ibn Hazm, accepted the lineage of Muttalib, brother of the great-grandfather of the Prophet Muhammad, Hashim (İbn Kudâme, 1998: IV/111) There is an opinion in this direction in the Hanbali school as well. Ahmed ibn Hanbal's son Abdullah stated that the lineage of Muttalib getting alms are not halal either, as the lineage of Hashim and Muttalib are at the level of two branches in the same tree (Ylldırım, 1986: III/478).

Imam Shafi is descended of Muttalib. There is an agreement between the Shafi'i that giving alms to Muttalib's lineage is nor halal. Imam of Zahiri school, Dawud al-Zahiri is also in the opinion that Muttalib's descendants cannot be given alms. Following reports are given as evidence on the subject 
in the Islamic school books, primarily Imam Shafi'i's book alUmm:

Imam Shafi, about the issue of being haram for Muttalib's lineage to receive alms, says the following: "Rasulullah (PBUH) accepted Muttalibis the same with Hashemites on the issue of dividing the booty. No other Quraish clans were given from this share. Rasulullah gave this to the Hashemites and the Muttalibis in exchange for the alms-share that he accepted haram for them" (Şâfii, 2001: II/88).

When Prophet distributed the shares of the close relatives to the Hashemites and the Muttalibis, Uthman and Jubayr ibn Mut'im came and asked Prophet "Oh Rasulullah! Our closeness to you Hashemites is the same with the Muttalibis to you. You gave them a share, but why did not you give it to us?" Then, the Prophet Muhammad said, "Us and Banu Muttalib are one like this" and joined his fingers together (Şafi, 2001: II/88). Besides, the Prophet, to express their support and help to him, said: "They (Muttalibis) did not leave us in both Jahiliyyah and Islam" (Serahsi, 1989: X/12).

b) Those who do not accept Muttalibis as al-Muhammad: according to the majority of Hanafi, Maliki, and Hanbali scholars al-Muhammad only covers the Hashemites (İbn Nüceym 1997: II/429).

The proofs of them are as follows: In the $60^{\text {th }}$ verse of Surah at-Tawbah concerning alms, there is a common expression as 
"Zakat is for poor and rich". Poor in the Muttalibis enters the scope of this verse. Hashemites excluded from this general provision with this hadith: "Alms are not required for alMuhammad" (Ahmed b. Hanbel: I / 200). It is necessary to limit this ban only to the Hashemites. Comparing Muttalibis to Hashemites is not right. Because Hashemites are the Prophet's relatives and closer to him and more honorable. Muttalibis also get one-fifth of the booty are due to the abstract kinship (because they are relatives). Indeed, the lineages of Nawfal and Abdu Shams have the same affinity, but no booty was given to them. Muttalibis are given the right to partner with Hashemites in taking share from the booty because they helped Islam. This partnership in nusret (helping to Islam) does not require a similar provision in the case of not taking alms (İbn Kudâme, 1998: IV/111).

5- Mawali of the Hâşimoğullari: There are two approaches to whether the slaves who are released (mawali) by the Hashemites can be given zakat or not.

a- Hashemites' mawali cannot be given alms. Some scholars, especially Hanafis, are of this opinion. In the hadith, the word "sadaka" (charities) includes both the fard (compulsory) alms and supererogatory/voluntary charities. Some hadiths about this have been brought as evidence. The Hanafis stated that the Hashemites' mawali were to be 
accepted as Hashemites only in the case of the prohibition of alms (Kâsânî, 1986: II/483).

Abu Rafi (r.a.), one of the (former) slaves of Rasulullah (PBUH), assigned a man from the Banu Mahzun tribe (Erkam ibn Erkâm) to collect alms. The man made a suggestion to Abu Rafi: "I will give you some (share) from the charities if you accompany me (for collecting alms)". Abu Rafi answered him, "without going to Rasulullah and getting permission I cannot come with you"; and he went to Rasulullah (PBUH), asking about it. The Prophet said to him: "Certainly, charities (alms) is not halal to us, and a mawali (former slaves) of a tribe is counted from them (Tirmizi, Zekat: 25; Nesâi, Zekat: 97).

b- Hashemites' mawali can be given alms: The majority of scholars said that the Hashemites' mawali could be given alms. Because they are not the relatives of the Prophet. Like other people, they cannot be avoided. Because they do not receive from one-fifth of the booty for not receiving alms. They are not given shares from booty. Like other people, it is not lawful to make it haram for them (İbn Kudâme, 1998: IV/110) It is a matter Hanafi people also accept that legally Hashemites' mawali is not same as Hashemites. However, this is an exception because there is special evidence on alms (Kasani, 1986: 483) 
Hanbali Ibn Qayma gives an intellectual argument to the above objection that the Hashemites' mawali is not from the Hashemites so that it is not right to prohibit those who are in need from alms: Hashemites can be an inheritor to their mawali through the asebe way. Therefore, giving them alms like Hashemites should not be halal. (İbn Kudâme, 1998: IV/110). This justification is not reasonable. After the alms is given to a person its qualification changes. The person with this property can give it to those who are not allowed to receive alms. Indeed, as a charity, Barira, who was the freed concubine of Aisha, was given a piece of meat. When the Prophet came home, there was nothing other than this meat as food. Aisha did not want to offer this meat to Prophet by thinking that it would not be halal because of being a charity. The Prophet thereupon said, "That meat is alms for Barira, but for us, it is a present" (Buhari, Talak: 14).

There are several reasons for the misappropriation of alms and charity to the al-Muhammad. One of them is to prevent gossip and political propaganda as the Prophet is giving goods unjustly to his relatives and favoring them because of the bad faith people among the public who are in need. Indeed, Uthman's opposition disseminated propaganda about him favoring his relatives and giving them goods unjustly. There is also a concern that in the prohibition of receiving alms for the relatives of the Prophet, which is they 
may be offended by the comments "they receive even if they do not have right to do so" in the society and the respect for them may be shaken.

There are explanations in the fiqh books and hadith commentaries with an analogy to the principle the water used in the ablution becomes dirty after fulfilling a fard, in this manner, accepting dirty goods for the relatives of the Prophet is not an appropriate behavior for their position and would decrease the nobility, honor, and value they have.

The fact that the heads of states favored their relatives and benefited them from the facilities of the state and enriched them and collected the economic opportunities of the country in certain hands has been seen throughout history. Islam religion has not seen the collection of goods as a monopoly in certain hands as lawful (Habergetiren, 2015: 194). The situation together with its rationale is clearly stated in the verse on the subject (al-Hashr, 59/7). The fact that the Prophet prohibited alms to his own relatives can be regarded as a result of similar sensitivity.

\section{The justification of the prohibition of zakat and charities to the Prophet's relatives}

There are four different juristic reasons for the prohibition of giving alms to the relatives of the Prophet: 


\section{1-Giving a certain share of the booty (one-fifth of the booty)}

The reason alms has been forbidden to al-Muhammad is that they have been given a certain share from the booty to them as a price/ivaz. When this price (ivaz) is not given it is halal for them to receive alms. The Maliki school advocates this view. There are also those who defend this view from the Shafi'i and the Hanafi school (Karadâvî, 1973: 732) Ibn Humam, one of the Hanafi scholars, did not accept this view. He stated that these two were different (İbn Hümam, 2003: II/277).

The verse that counts the consumables of the booty is as follows: "...And know that anything you obtain of war booty - then indeed, for Allah is one fifth of it and for the Messenger and for [his] near relatives and the orphans, the needy, and the [stranded] traveler" (al-Anfal, 8:41) Among those given to them are people such as the poor and the traveler, who is also given alms. They are not mentioned in those who are given prices (ivaz) instead of alms. There are common places between the places where the income of the booty will be spent and the places where the alms revenues will be spent. The relatives of the Prophet are among those who will be given this item while are not among those who will be given alms. Therefore, the share given from the booty cannot be called as a price (ivaz). 
In a hadith narrated from the Prophet on the subject is as follows:

"O Hashemites, instead of this (zakat) Allahû Teâla (cc) has given you one-fifth of the booty as a price" he declared (Taberanî, 1994: XI-217). This hadith is mentioned in the authentic jurisprudence books of Hanafi. Zeylai, in his exposition and commentary study on the hadiths of famous jurisprudence book of Hanafis, el-Hidâye, says the narration with wording "price:ivaz" does not appear in the hadith books, but there are other hadiths in this regard (Zeylai, 1997: II / 403).

According to the Hanafi people, Ibn al-Abidin believes if no shares are given from the booty, al-Muhammad can be given alms as well. «It is absolute not to give alms to the Hashemite.» So this provision is valid at all times. Similarly, there is no difference between giving alms to each other and receiving from others for them. According to Abu Isme, Abu Hanifa said in his time that to giving alms to the Hashemites was permissible. Because the reason for not to be given alms, booty, was not received by Hashemites because of the negligence of people in the booty handling. When they do not receive the price, (the Hashemites instead) return to the never (receive the share of alms provision) (İbn Abidin, 1994: III / 299). 
Those advocated Ahl al-Bayt should be given a share from alms suggested two reasons:

a- Not giving alms is because of giving them a share in the booty as a price. They can fulfill their needs with their share of the booty. When the share of the booty decreases, it is permissible to give alms to the people in need from the Ahl al-Bayt. (Zeylâî 1997: II/487)

b- In the state of necessity, the haram becomes halal. If the people of Ahl al-Bayt are in a position not to meet their needs due to poverty, it is halal to receive alms in the amount that they can have a relief from the hard situation they are in. In the state of necessity, if the person cannot meet the basic needs, they can meet the needs with the things counted as haram. In this case, there are two types of haram. The first is al-haram li-datihi and the other is alharam li-gayrihi. As alms haram corresponds to the al-haram li-gayrihi group, one can meet their needs with that. In this case, necessities turn the things haram into mubah (permissible).

It would be reasonable to think juristically that Prophet's relatives cannot be given alms is giving a share of the booty to them. We can say that this is also reasonable in political, social, and economic terms. One of the Prophet's relatives must be from the head of state for them to be subjected to an accusation that they are taking alms although they do not 
have the rights to do so. However, when the administration of the state is in someone other than the Ahl al-Bayt, such an accusation for al-Muhammad will have disappeared.

\section{2-The rationale for the taabudi (above criticism) (the reason} not being known)

If a provision is taabudi that means its rationale cannot be determined, therefore, it means that the provision must be accepted as it was to the Day of Judgment. Scholars then say that this is a general provision after counting Hashemite among those who cannot be given alms. This approach evokes the idea that not giving alms to the al-Muhammad has a known cause that can be rationally explained. Although there are many explanations about the wisdom of this prohibition, still not being able to mention a rationale, means this provision cannot differentiate in different situations.

As a matter of fact, when a provision is referred to as absolute, it requires the continuity of that provision, which implies that the prohibition of alms on the Ahl al-Bayt would continue until the Day of Judgment (Erzen, 1998: 8)

3- Being close to the prophet: Honor, nobility, and superiority: Juridical rationale aspect

Those who believe that the provisions can be given not only by means of reason but by wisdom mention several wisdoms 
about the justification for the prohibition of alms and charity to the Prophet and his family.

The reasons for the prohibition of charity and alms to the Prophet was given as:

The Prophet is the most honorary people of all. He has shares (right of the president to elect a share of booty goods) from booty. So, fard and supererogatory charity is haram to him (İbn Kudâme, 1998: IV/116).

All kinds of alms and charity are haram to the Prophet. His staying away from this is a sign of his prophethood. As a matter of fact, the acceptance of the gift by the Prophet, but refusing the charity, was influential for Salman the Persian's conversion to Islam. Salman identifying his prophethood was possible with seeing this feature. Likewise, when a meal was brought to the Prophet, he would ask if it was charity or gift. If it was a charity, he would hand it to his friends, if it was a present he would eat it as well (Buhârî, Hibe:5; Müslim, Zekât:175).

The reason for the prohibition of alms for Prophet's relatives just like himself is to show the respect and reverence to our Prophet against his relatives as well (Kasani, 1986: 483). Just like Prophet was careful about the alms and charity of the people, his relatives should also be careful about it.

The fact that the relatives of the Prophet are not in need of the charity and alms of the Muslims and that those who are 
in a position to receive alms charity are accepted in socially low levels. However, the fact that some of the companions [of the Prophet] are appointed as alms officers and that their wages are paid from the alms fund shows that it was not bad and undesirable to receive alms at the time. Besides, the fact that Abu Bakr has declared war on those who refuse to pay the alms implies the importance of the alms itself as well as taking the alms and giving them to the needy. It would not be reasonable to wage war for that if alms was a nasty and bad thing and if there was something bad and undesirable in getting alms.

Prohibition of receiving alms for the Prophet's relatives may be considered as a precautionary measure in order to prevent their dignity in the society being harmed by the allegations and accusations that they gather and collect goods from people and embezzle them, and exploit the people.

\section{4- Because it is accepted as the dirt of the people}

Describing alms as the dirt of people's hands (goods) is based on hadiths. The Prophet (PBUH), when forbidding taking alms to the Ahl al-Bayt, states that it is the dirt of the people. The expression of the dirt of the goods is understood not as genuine dirt but as spiritual dirt. For spiritual dirt, ablution water is given in fiqh books as the example. There are three different views in the Hanafi school regarding the 
legal status of the ablution water. Abu Hanifa calls it as the strong dirt (necaset-i galiza), Abu Yusuf as light dirt (necaset-i hafife), Imam Muhammad as clean but not cleaning water. The question of it is the dirt of people/their property is our research subject and we will convey the explanations in the history of jurisprudence and try to reveal our different opinion.

a. a. The reason for the accepting the alms goods to be given to the Ahl al-Bayt as dirty

As mentioned, it is based on hadiths that the alms goods are counted dirty. The Prophet while forbidding alms to the Hashemites he showed the reasons as it is dirty. There are two possibilities for it is [counted] to be dirty.

Firstly, this issue is taabudi, so the rationale cannot be known intellectually. So, it is accepted as it is. If alms goods being dirty is accepted as a taabudi issue, the reasons cannot be determined. However, some explanations can be made from the wisdom perspective.

Secondly, it has a reason to be counted as dirty. If the reasons are determined, the situations with the same reasons exist can be located and judged accordingly.

In the fiqh books, the explanations are made for the alms given to Ahl al-Bayt counted as dirty as following. 


\section{b. The opinion of the fiqh jurists about the reason of the counting alms goods as dirt}

In the books of figh, the alms is compared to the ablution on being dirty (Ibn Mâze, 2000: III/214).

Something that is made worship with would be contaminated because of this worship. The water becomes dirty water after ablution is taken with it. The amount a person pays his alms becomes a dirty commodity.

The Prophet's family cannot take these dirty goods. They are superior in honor and nobility.

From the verse "Take, [O, Muhammad], from their wealth a charity by which you purify them..." (Tevbe, 9: 103) it is understood that the alms cleans a person. The goods that are made cleaning with itself becomes dirty. Al-Muhammed is exempt to take this kind of dirty thing with respect to the honor and their position. Indeed, the hadith also referred to it as "the dirt of people" (İbn Kâsım, 1397: II /99).

Ibn Humam stated that the prohibited property for the Ahl al-Bayt was the fard (compulsory) alms because with it the fard is fulfilled. Therefore, the supererogatory/voluntary charities in which a fard is not fulfilled is not dirty and it is not haram to take it. This situation has been compared to taking ablution for cooling purposes (İbn Hümam, 2003: II/277; İbn Mâze, 2000: II/495). Ibn Hümam says that this comparison is not right: he explains it at length. Here is the 
matter in the comparison, is the issue that has the judgment on, which is alms good being dirty for the Ahl al-Bayt in this case. There is no evidence that the ablution water is dirty. For this reason, the issue of used "water becoming dirty" in the used waters section, is compared with the "goods given as alms becoming dirty". Here, too, there is a difference (kiyas maal fârik). The provision has the requirement of taking a fard or supererogatory ablution for a water to be polluted. Therefore, the water taken in supererogatory ablution is also dirty according to Hanafis and cannot be used again for ablution (İbn Hümam, 2003: II/279).

Again, in the famous hadith when Hasan took an alms date to his mouth, the Prophet said to him that "kih, kih, throw it, that is neither halal to Muhammad nor to his family" (Buhari, Zekât:60, Cihad:188). In fact we behave similarly to prevent children from swallowing it when they take something should not be eaten in their mouth. There are different narrations about the hadith by different people. Considering all of this, the sensitivity of the Prophet about not allowing his family to eat/use/take alms is understood more clearly.

\section{c. Evaluation of the counting the alms good as dirt}

The following can be argued about the rationale for the alms goods to be considered as dirt: 
1- The al-haram li-gayrihi concept: The al-haram li-gayrihi concept in Hanafi school gives us important clues about the explaining the hadith "alms is the dirt of the goods".

Islamic jurists have also counted the things they considered as haram as dirty/nasty/unclean. The basic principle of this subject is revealed in the following verse.

"O you who have believed, indeed, intoxicants, gambling, [sacrificing on] stone alters [to other than Allah], and divining arrows are but defilement from the work of Satan..." (Maide, 5: 90).

Things that are haram are examined in two parts. Al-haram li-datihi is the things that are originally haram such as wine and pork. Al-haram li-gayrihi things are halal things, but it is haram when it is found with something that makes it become haram. This can be explained by the following example:

It is permissible to eat apples. Yet, eating the apple owned by another person is forbidden (haram) without their permission. Because a person can get the apple which belongs to someone else without their permission or by robbing them. These two behaviors are also prohibited. The reason why the apple is haram is not the origin of the apple, but it is due to eating it without taking it from someone else with a legitimate reason. 
Allah declares "And from their properties was [given] the right of the [needy] petitioner and the deprived" in Qur'an (Zâriyat, 51/19). This right lies in one's property must be given to the owner. Where this should be given as alms is given in the following verses: "Zakat expenditures are only for the poor and for the needy and for those employed to collect [zakat] and for bringing hearts together [for Islam] and for freeing captives [or slaves] and for those in debt and for the cause of Allah and for the [stranded] traveler - an obligation [imposed] by Allah. And Allah is Knowing and Wise" (Tevbe, 9/60). When the alms that in fact belongs to others is not given to their place, it is haram to use them because of the usage without the owner's permission.

From the verse "Take, [O, Muhammad], from their wealth a charity by which you purify them...", it is understood the alms given away clears the remaining property, and thus, the removed part is dirty. Even, in this respect, the water used in the ablution is not clean was likened to the alms [good] given is not clean. It is explained as cleaning was carried out with both of them and they were contaminated. However, Ibn Humam found this explanation to be wrong in terms of both narration and the wisdom (İbn Hümam, 2003: II / 279). The goods given as alms by a person cannot be haram and dirty in itself. Because Almighty Allah in many verses orders giving alms as a prayer together with salah. It 
is unreasonable that Allah Almighty has ordered a dirty and haram thing to be given as a form of worship. Likewise, it is not reasonable for Muslims in need take this dirty property, which is their right, and use it. The use and exploitation of such prohibited/haram and dirty things shall be permitted only in the state of necessity. However, alms is basic worship and the alms is in a basic and central place in the Islamic fiscal law. Therefore, the alms good being dirty and haram is about the people that cannot be given alms. According to this, it is forbidden for people who are rich in religion to take alms, because in this case, they get what take what belongs to the needy, even though they are not in need of that. To get someone else's right illegitimately is haram, hence, taking the alms even though they are not entitled to it makes the alms good haram for them.

Since these people cannot be given alms, it will be al-haram li-gayrihi for them to receive alms. In other words, they are taking dirty property. The thing that is halal for those who are permissible to take alms is haram for them. Those who give alms to them do not fulfill their alms obligation.

This part with the amount of alms in one's commodity is not halal for that person from the moment the alms accrued. This part of the commodity becomes "vesih=dirty" for its owner. Therefore, it is expressed as "alms is the dirt of the goods". 
This part is halal and mubah (permissible) for those who are allowed to receive alms. It does not carry any dirt either.

2- Prophet forbidding giving alms to his own family, it is being dirty due to this ban: It is Prophet himself declared the alms goods is haram for his family. Since haram goods are also dirty, al-Muhammad cannot benefit from it. Alms good for the prophet's relatives, even if they are poor and in need, becomes non-halal/haram because of this prohibition. There may be people who are unable to meet their basic needs from Prophet's relatives. These people would meet their needs with alms if they were not relatives of the Prophet. The Prophet has forbidden this, but he stated that those who need would take the share from "hums (booty)" and "this will satisfy your needs", he said. Therefore, the needs of the poor people of the Ahl al-Bayt will be from the state's hums (booty) item.

The Prophet forbade alms good to the Ahl al-Bayt and showed at "hums" as the source for those in need. If they took the alms despite this, they would have taken the "dirt of people's property", he expressed. We can explain this in the following way.

The good given by the wealthy as alms is dirty. In this case, a dirty good can be used by only a desperate person. It is not permissible for anyone else to eat alms good. None of the Islamist jurists has understood the alms in this way. This 
understanding is not either true. In fact, people who are responsible for collecting alms are not desperate, but they get a share of the alms. There are many companions who are not Ahl al-Bayt take alms and satisfy their needs. It is not reasonable/logical to think that these people who are very meticulous about haram and dirt will condescend to alms that is dirty.

To his relatives who wanted to be alms officer and collect the alms, so that they can have a share and use it for themselves, The Prophet said it is forbidden to the Ahl al-Bayt to take the dirty good. In this case, for the situation of the people in need from the Ahl al-Bayt, he said, "you have a share on one-fifth of the booty and this is sufficient for you". Many things can be said in the context of the wisdom of the prohibition of alms to the Ahl al-Bayt. But, what would be the situation if the share allocated from the booty to the needy of the Ahl al-Bayt is not given? This issue has been discussed in the research of the scholars since the period of the Islamic school imams.

\section{Conclusion:}

Alms is one of the institutions of social solidarity in Islam. It is a religious duty to find the people who are in need and to meet their needs. For this reason, both the people who give and take the alms should meet a few conditions. Since this is not only a social issue but also a religious obligation, it is 
necessary to the research and determine whether the person who will receive the alms has the right to receive it or not. There are features that should not be present next to the characteristics that must be found in the alms receivers. One of these conditions is that even if they are in need they should not be a relative of the Prophet. The religion, apart from the alms, has allocated a fund for them from the booty and fortune income and provided for them to fulfill their needs. It has been thoroughly examined by the jurists that the ban on taking alms for those in need in the situations where there are no such sources of income. In this case, there are some scholars saying they cannot take alms, some saying they can receive supererogatory charities, as well as some saying they can receive alms and charities whether it is fard or supererogatory to fulfill their needs.

The good given away as alms being dirty is based on the hadiths of the Prophets and is one of the issues that fiqh works put emphasis on. While the dirtiness of the alms good must cause an unfavorable view against alms, it is generally perceived as a threat and warning for those who do not deserve to receive alms in practice. For the relatives of the Prophet, alms was considered a spiritual dirty commodity that should be avoided and it was stated that taking alms would harm their dignity. 
In the books of Islamic schools, it is mentioned that one is performing worship with giving alms away, thus cleansing their sins, the good given away dirtied. Kemaleddin Ibn Hümam rejected and stated that this approach would not be correct with a number of reasons and explanations. However, he did not come up with a convincing solution either.

We believe that the concept of al-haram li-gayrihi is an appropriate methodological basis in explaining the contamination of the goods. Accordingly, the alms was accepted as dirty and haram for those who are not allowed to receive alms, since it is illegally obtaining the right of someone else whose alms receiving is halal. For those who are capable of taking alms, this property is their legitimate right and is clean and is halal.

The fact that the Prophet's relatives cannot be given alms is about the respectable position they are in socially and politically, and to protect their position without gossips and accusations that they are living based on alms. Some argued that since after the Prophet the administration went out from this family forever, such an accusation and claim had no grounds, and so the needy ones [of the relatives] can receive zakat. Despite the fact that there were no special allowances allocated to them, it was expressed by many scholars that 
this prohibition would continue as they were continued to be the relatives of the Prophet.

In addition to being meticulous, the introduction of a legal set of regulations and restrictions is one of the fundamental principles that are important in terms of Islamic law and Islamic economics in order to ensure that the heads of state or close relatives of the officials who hold economic opportunities, politically and socially, are not subject to accusations that they are unfairly using the means of the state. 


\section{References}

Ahmed b. Hanbel (1995), Müsned tahkik: Şuayb Arnavut, Müessesetür Risâle, Beyrut.

Aynî, Bedreddin (1990), el-Binâye ale'l-Hidâye, Dâru'l-fikr. Behûtî, Mansûr b. Yûnus (2003), Keşşâfu'l-kınâ', Dâru âlemi'l-kütüb, Riyad.

Beyhaki, Ebû Bekr Ahmed b. Huseyn b. Ali (2003), Sünen, Dârü'l-kütübi'l-ilmiyye, Beyrut.

Buhârî, Muhammed b. İsmâil (1980), Sahih, tahkik fuad Abdülbaki, Matbaatus selefiyye, Kahire.

Buzpınar, Şit Tufan (2006), Nakîbüleşrâf, DİA, XXXII, 324, Ankara.

Darimi, Abdurahman Semerkandî (2000), Sünen, Dâru'1muğnî, Riyad.

Derdir, Ahmed, Şerhü'l-kebir, İhyâü'l-kütübi'l-Arabiyye.

Erzen Abdülkadir, (1998), Zekâtü'l-mâl tahillü li'l-âl, Silopi, (mahtuta).

Habergetiren, Ömer Faruk, (2015), İslam Hukukunda Sermaye ve Sermaye Hareketleri, Kitâbî, İstanbul.

Haraşi, Ebû Abdillah Muhammed b. Abdillah el-Mâlikî (1318), Şerhu muhtasarı Halil, Bulak,

Hattab, Ebû Abdillah Muhammed el-Mağribî, (1995), Mevahibü'l-celil, Dârü'l-kütübi'l-ilmiyye, Beyrut. İbn Âbidîn, Muhammed Emin (1994), Reddü'l-muhtâr alâ dürri'l-muhtâr, Dârü'l-kütübi'l-ilmiyye, Beyrut. 
İbn Hacer el-Askalânî (2005), Fethü'l-Bârî şerhu sahihi'lBuhârî, Dâru Taybe, Riyad.

İbn Hümam, Kemâleddin (2003), Fethu'l-kadir Dârü'lkütübi'l-ilmiyye, Beyrut.

İbn Kâsım el-Âsımî (1397), Ravzu'l-murbi' Şerhu zâdü'lmüstenki'.

İbn Kudâme, Ebu'l-Ferec (1994), Şerhu'l-Kebir ale'l-mukni', Kâhire.

İbn Kudame, Muvaffakuddin (1998,) Muğni, Dâru âlemi'1kütüb, Riyad.

İbn Mâze, Burhaneddin (2000), El-Muhitü'l-Burhânî, Beyrut. İbn Nüceym, Zeynülâbidîn Zeyn b. İbrahim (1997), Bahru'rrâik şerhu kenzi'd-dekâik, , Dârü'l-kütübi'l-ilmiyye, Beyrut. Karadâvî. Yusuf (1973), Fıkhu'z-zekât, Beyrut sh:728-739.

Karafî, Şihâbüddîn Ahmed b. İdrîs (1994), Zahire, Dâru'lgarbi'l-İslâmi, Beyrut.

Kâsânî, Alâuddîn b. Mes'ûd (1986), Sedaiu's-Sanai', Dârü'lkütübi'l-ilmiyye, Beyrut.

Müslim b. Haccac (1998), Sahih, Riyad.

Nesai, Ahmed b. Şuayb (2001), Sünen, tahkik Şelebî, Müessesetü'r-Risâle, Beyrut.

Öz, Mustafa (1994), “Ehl-i beyt” DIA, X/498-501, İstanbul.

Özel, Ahmet, (1989) “Âl”, DIA, II/305-306, İstanbul

Serahsi (1989), Mebsut, Dâru'l-marife, Beyrut. 
Şafii, Muhammed b. İdris (2001), Kitabul-üm, Dâru'l-vefâ, Mansure.

Taberânî, (1994), Mu'cemu'l-kebîr, Mektebetu İbn Teymiye, Kahire.

Taberî, Muhammed Cerir (1968), Tarih, Dâru'l-maarif, Beyrut.

Tehanevi, Muhammed A'lâ b. Alî (2001), I'lâu's-sünen, Dâru'l-fikr, Beyrut.

Tirmizî, Ebû Îsâ Muhammed b. Îsâ (1998), Sünen, Dâru'lgarbi'l-İslâmi, Beyrut.

Yardım, Ali, (1994), "Dürre bint Ebû Leheb", DIA, X/30-31, İstanbul.

Yıldırım, Celal (1986), Kaynaklarıyla Ahkâm Hadisleri, Uysal Kitabevi: Konya.

Zekeriya el-Ensârî, Esnâl metâlib fi şerhi Ravzi't-tâlib, Dârü'l-kütübi'l-İslâmiyye, ty.

Zeylâî, Cemalüddîn Abdullah b. Yûsuf b. Muhammed, (1997), Nasbu'r-râye li ehâdisi'l-Hidâye, Müessesetü Reyyân, Beyrut. 